\title{
Development of Whatsapp Instant Messaging Applications as Online Learning Media to Improve Social Science Learning Outcomes in Class VIII SMP Negeri 2 Sumbul Academic Year 2020/2021
}

\author{
Esra PH Sitanggang ${ }^{1, *}$ Hamonangan Tambunan ${ }^{2}$ Naeklan Simbolon ${ }^{3}$ \\ ${ }^{123}$ Universitas Negeri Medan, Medan, Indonesia \\ *Corresponding author.Email: esrasitanggang13@gmail.com
}

\begin{abstract}
This study aims to produce a WhatsApp instant messaging application product as an online learning medium in social studies subjects that is feasible and effective. This type of research is development research that uses the Borg and Gall development model. The results show: (1) The learning material expert test is included in the very feasible criteria, namely with a score of $93.26 \%$. (2) The learning instructor design expert test is included in the very criteria. feasible with a score of $92.36 \%$. (3) The learning media expert test is included in the very feasible criteria, namely with a score of $92.96 \%$. The results of hypothesis testing prove that there are differences in student learning outcomes who are taught using the WhatsApp instant messaging application product in the form of learning videos with students who do not use the WhatsApp instant messaging application product.
\end{abstract}

Keywords: Whatsapp instant messaging application, Social Sciences.

\section{INTRODUCTION}

Science and technology have changed today's world civilization. With these rapid developments we have arrived at the fourthgeneration industrial revolution (industrial revolution 4.0) where this revolution is marked by the emergence of the most up-to-date modern technology with computerized and digitalized systems that support the connectivity of all components in the world. industry and other fields Corona Virus (Covid-19) is a grievous disaster for the whole world, including Indonesia. Covid-19 is a disease that is susceptible to infection due to the newly discovered variant of the corona virus. The emergence of the Covid-19 pandemic, automatically changes the total pattern of all human activities and activities throughout the world. Many things were carried out in an effort to stop the spread, as well as transmission, such as social restrictions in all forms of activity, including learning activities. According to UNESCO, there are 1.5 billion school-age children affected by Covid-19 from 188 countries: 60 million are in Indonesia. This condition causes learning in schools to be abolished. This matter is based on the Minister of Education and Culture regarding Circular No. 4 Year 2020, which states that learning must be done online from home (distance teaching and learning activities). As happened in SMP Negeri 2 Sumbul for example, this junior high school is one of the schools located in rural areas. It has good building infrastructure. However, due to the impact of the pandemic and the recommendation of the local government which states that educational units are prohibited from conducting face-to-face learning processes. Thus, SMP Negeri 2 Sumbul is still carrying out the teaching and learning process without face to face. Hadisputra (2020) mentions that there are many ways to optimize online learning. The development study focuses on developing social media using the WhatsApp application as a support for social studies teaching and learning media. In this regard, the researcher conducted research and development with the title WhatsApp Instant Messaging Application Development as an Online Learning Media to Improve Social Studies Learning Outcomes in Class VIII SMP Negeri 2 Sumbul Year Teaching 2020/2021.

\section{METHOD}

This study is classified as a development/research and development (R\&D). Research and development methodologies are closely related to learning technology. 
Studies in the field of learning technology are already related to problems in developing products and designs, especially media, teaching materials, and learning systems. It is known that learning technology can be defined as the practice and theory of design, use, management, development, and evaluation of resources for learning (Setyosari, 2013). On that basis, this study seeks to improve learning media based on student needs.

The product design in this study was carried out in 9 stages. The 9 steps of the development model proposed by Dick \& Carey (2001) are: (1) needs analysis to identify goals, (2) instructional analysis, (3) learner and context analysis, (4) formulating performance goals, (5) developing research instruments, (6) developing learning strategies, (7) developing and selecting learning materials, (8) conducting formative evaluations, (9) revising. The following are the stages of developing the Dick \& Carey model to product formation, namely from the stages of needs analysis and identification of goals to the development of learning materials. Conduct formative evaluations that can be used for system feedback. It goes through three stages; a) individuals, b) small groups, c) field trials.

System revisions were made based on the feedback obtained during the formative evaluation. There are two kinds of revisions here; a) changes to the content or substance so that it can be more effective and accurate, $b$ ) changes to procedures. Summative evaluation emphasizes the achievement of the learning process through the achievement of test scores. The development procedure describes the procedures for developing a product. The procedures or procedures in this study use two stages, namely developing the WhatsApp instant messaging application through product design, while the next stage is finding out the effectiveness product. The steps for developing the WhatsApp instant messaging application to support online learning for class VIII Social Studies students at SMP Negeri 2 Sumbul adapt the 10-step development procedure.

\section{RESULT AND DISCUSSION}

\subsection{Teaching using Whatsapp}

Based on studies that have been carried out on social studies learning outcomes, it concludes that if the score of learning outcomes for material advantages and limitations between spaces, as well as the role of economic actors and in an economy with WhatsApp instant messaging application media products in the form of learning videos, the lowest score is 60 while the highest score is 60. high 95, mean score $X=84.5$, Standard deviation $(\mathrm{SD})=9.94$, the results of the calculation can be seen in Appendix 9, page 240. This means that almost all of the total number of students reach the absorption capacity of KKM, so it can be mentioned If students are taught to use this media, it is considered effective in terms of the quality of their learning.

To observe student scores, use interval classes, namely absolute inter-frequency scores as the number of students scoring learning outcomes, and relative frequency as the percentage of learning outcomes score.

Table 1. Social Studies Learning Outcomes Using WhatsApp Instant Messaging Application Media Products

\begin{tabular}{|c|c|c|c|}
\hline Class & $\begin{array}{c}\text { Class } \\
\text { Interval }\end{array}$ & $\begin{array}{c}\text { F. } \\
\text { Absolute }\end{array}$ & $\begin{array}{c}\text { F. } \\
\text { Relative } \\
\mathbf{\%}\end{array}$ \\
\hline $\mathbf{1}$ & $60-65$ & 3 & $10 \%$ \\
\hline $\mathbf{2}$ & $66-71$ & 1 & $3.4 \%$ \\
\hline $\mathbf{3}$ & $72-77$ & 2 & $6.6 \%$ \\
\hline $\mathbf{4}$ & $78-83$ & 5 & $16.6 \%$ \\
\hline $\mathbf{5}$ & $84-89$ & 4 & $13.3 \%$ \\
\hline $\mathbf{6}$ & $90-95$ & 15 & $50 \%$ \\
\hline Amount & & $\mathbf{3 0}$ & $\mathbf{1 0 0}$ \\
\hline
\end{tabular}

The results of social studies learning using the WhatsApp instant messaging application as a learning video are depicted in the form of a histogram in Figure 1.

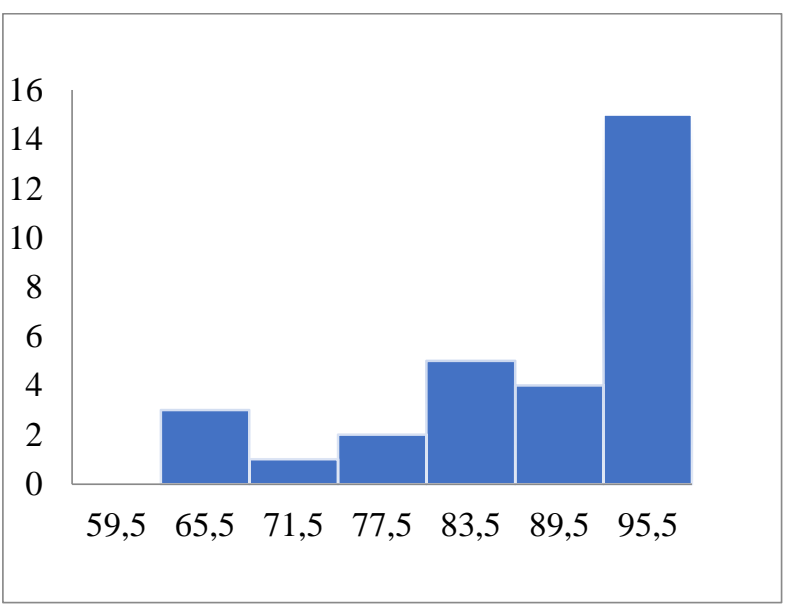

Figure 1. Histogram of Social Studies Learning Outcomes with Instant Messaging Application Media Products whatsapp.

\subsection{Teaching without WhatsApp}

Based on studies that have been carried out on social studies learning outcomes, it concludes that if the score for learning material advantages and limitations between spaces, as well as the role of economic actors and in an economy without WhatsApp instant messaging application media products in the form of (conventional) learning videos, the lowest score is 40 . and the highest score is 90 , the average score $X=63.66$, standard deviation $(\mathrm{SD})=9.9$, the results of the calculation can be seen in Appendix 9 page 238. Based on this it can be said that the majority of the total number of students achieve absorption KKM, which means if the learning effectis not 
following the quality of learning. Through the results of these calculations, social studies learning in this class is stated to be still less effective.

To observe the scores of students who use interval classes, namely absolute inter-frequency scores: the number of students who score learning outcomes, and the relative frequency, the total percentage of learning outcomes scores. A description of the results of social studies learning on the material advantages and limitations between spaces, as well as the role of economic actors as well as in an economy without the WhatsApp instant messaging application (conventional) media products are listed in Table 2 .

Table 2. Social Studies Learning Outcomes Without Using WhatsApp Instant Messaging Application Media Products (Conventional)

\begin{tabular}{|c|c|c|c|}
\hline Class & $\begin{array}{c}\text { Class } \\
\text { Interval }\end{array}$ & $\begin{array}{c}\text { F. } \\
\text { Absolute }\end{array}$ & $\begin{array}{c}\text { F. Relative } \\
\text { \% }\end{array}$ \\
\hline $\mathbf{1}$ & $40-48$ & 1 & $3.3 \%$ \\
\hline $\mathbf{2}$ & $49-57$ & 5 & $16.6 \%$ \\
\hline $\mathbf{3}$ & $58-66$ & 15 & $50 \%$ \\
\hline $\mathbf{4}$ & $67-75$ & 6 & $20 \%$ \\
\hline $\mathbf{5}$ & $76-84$ & 2 & $6.6 \%$ \\
\hline $\mathbf{6}$ & $85-93$ & 1 & $3.3 \%$ \\
\hline Amount & & $\mathbf{3 0}$ & $\mathbf{1 0 0}$ \\
\hline
\end{tabular}

The results of social studies learning without WhatsApp (conventional) instant messaging application media products can be depicted in the form of a histogram.

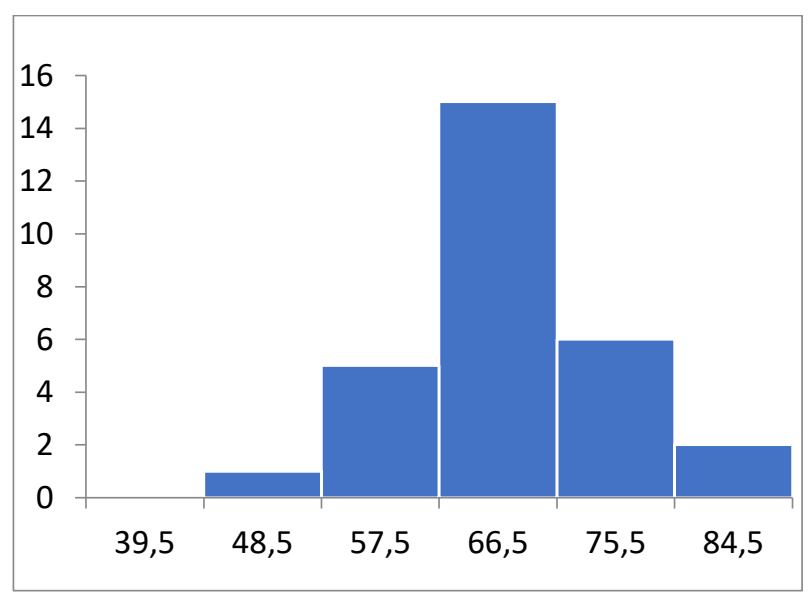

Figure 2. Histogram of Social Studies Learning Outcomes without WhatsApp Instant Messaging Application Media Products

\section{DISCUSSION}

Based on the results of validation and testing, the media product of the WhatsApp instant messaging application based on video learning material on the advantages and limitations of inter-space, as well as the role of economic actors and in an economy is very feasible to use at the teaching and learning stage.
Through these media, the teaching and learning process is carried out effectively. This matter can be considered through the teaching and learning stage when it takes place. The product can bridge students and teachers during learning activities even though online. Thus, even in conditions of distance learning, students remain active and still receive adequate explanationzs of material that can be accessed regardless of time or location.

Abdillah (2021) reveals that social media applications such as WhatsApp can bridge the learning process for conventional models with face-to-face systems, as well as for distance modes without reducing the effectiveness of learning. In line with Riyana (2007) states that to create a learning video that can optimize the activity and effectiveness of use, it is necessary to pay attention to its characteristics. One of the many criteria for the learning video in question includes: user-friendly (easy to use). This video media uses simple and understandable language, the delivery of information is helpful, including making it easier for users to respond, and access according to their wishes. Thus, it can be concluded that the data above proves that the use of this product is very feasible for students in social science material.

Media is said to be effective after showing satisfactory results as long as it achieves the stated goals. The effectiveness of learning can be measured through the quality of learning according to the narrative of namely the level of information presented so that students are easy to learn or the error rate is getting smaller. The smaller the error rate, the more effective teaching and learning activities for students are. Determining the effectiveness of learning depends on how much students master the objectives or often known as learning mastery. In this case, to see the effectiveness of the product, a product trial was carried out in the learning process. The effectiveness of the media is obtained through student learning outcomes. Miarso (2011) states the benchmarks that can determine how effective the teaching and learning stage is, namely: a) organizing the material well; b) effective communication; c) high enthusiasm related to efforts to master the learning material; d) being positive for studentse) giving grades fairly; f) flexibility in teaching and learning approach; g) appropriate learning outcomes for students.

Through the results of the study data processing, the average social studies teaching and learning outcomes after using the media product of the WhatsApp instant messaging application based on learning videos for class VIII students of SMP Negeri 2 Sumbul is 83.5. Social studies learning outcomes without WhatsApp instant messaging application media products (conventional) are 63.6. From this data, it proves that the WhatsApp instant messaging application media product for class VIII students of SMP Negeri 2 Sumbul is feasible and effective to use to optimize students' abilities. 
Riyana (2007) explained that to design learning videos that can maximize motivation, effectiveness, and user activity, that means it is necessary to develop learning videos according to or need to fulfill their characteristics. The learning video criteria include (1) Clarity of Massage. Through video media, students can examine all learning messages significantly and receive more complete information so that it will be stored in their memories for a long time; (2) Stand Alone. J. Eemp (1985) states that learning videos provide information, represent the stages, and suitability of skilled, short, and time-building teaching, including being able to influence behavior and can be repeated. Thus, the conclusion obtained states that learning media can maximize student demand for learning, focus on the material, open their minds, be responsive to questions so that the classroom atmosphere is more pleasant, maximize learning effectiveness, and improve the quality of learning outcomes.

\section{CONCLUSION}

Based on the results of data processing, the average value of the learning outcomes of students who are taught using WhatsApp instant messaging application media products on the material advantages and limitations of inter-space and the involvement of economic actors in an economy with student learning outcomes taught without using messaging application media products WhatsApp instant (conventional) on the advantages and limitations of inter-space and the involvement of economic actors in an economy shows that students who are taught using WhatsApp instant messaging application media products are "more effective" than students who are taught without using WhatsApp instant messaging application media products ( conventional). This is shown. Based on the results of the t-test to a significant level $=0.05$, the results of the hypothesis test for learning outcomes in the two classes after being given treatment mean that the value of t_count>t_(table) is $8.162>1.671$, which means that it is concluded that there is a rejection for $(\mathrm{Ho})$ while $(\mathrm{Ha})$ is accepted. The results obtained, namely, the research hypothesis, explains that social science learning outcomes increase when using the WhatsApp instant messaging application media product compared to without using the WhatsApp instant messaging application media product.

\section{ACKNOWLEDGMENTS}

First and foremost, I would like to show my deepest gratitude to my teachers and professors in my university, who have provided me with valuable guidance in every stage of the writing of this thesis. Further, I would like to thank all my family, my friends and roommates for their encouragement and support.

\section{REFERENCES}

[1] Abdillah, Leon A., Handayani, Trian., Rosalyn, Ellen R., Mukti, Yogi I., (2021). Collaborating Digital Social Media For Teaching Science And Arabic In Education During Covid-19 Pandemic. Journal Of Arabic Learning, Vol.4(1), p. 14-21.

[2] Abiodun, R., Daniels, F., Pimmer, DC, \& Chipps, J. (2020). A whatsappcommunity of practice to support new graduate nurses in South Africa. Nurse Education in Practice, 46 (1). 1-7.

[3] Adams, Tony \& Jones, Holman \& Ellis, Carolyn. (2015). Autoethnography: Chapter. Oxford: Oxford University press.

[4] Afnibar., Fajhriani, Dyla. (2020). Using Whatsapp as a Media Communication Between Lecturer And MahaStudents in Supporting Learning Activities (Study of UIN Imam Bonjol Padang Students. Jurnal Islamic Communication And Broadcasting, Vol. 11(1), p. 70-83.

[5] Ahmad, Rivai and Sujana, Nana. (2011). Learning Media. Bandung: Sinar New.

[6] Akram, Waseem. (2018). A Study on Positive and Negative Effects of Socialmedia on Society. International Journal of Computer Sciences and Engineering. Vol. 5(10). p. 347-354.

[7] Aljohani, M. (2018). Principles of "Constructivism" in Foreign LanguageTeaching. Journal of Literature and Art Studies, January 2017, Vol. 7, No. 1, p. 97-107.

[8] Anderson, Ronal H. 1994. Media Selection and Development for Learning. Jakarta: Grafindo Press.

[9] Anugraha, A. (2020). Barriers, Solutions and Expectations: Online Learning During the Covid-19 Pandemic by Elementary School Teachers. Journal of Education and Culture, Vol. 10 No. 3, 282-289.

[10] Appanna, Subhashni. (2008). A review Of Benefits And Limitations Of Online Learning In The Context Of Student, The Instructor And The Tenured Faculty. International Journal On ELearning. Vol. 7(1), p. 5-22.

[11] Arifin, Zainal. (2012). New Educational Research Methods and Paradigms. Bandung: PT. Rosdakarya Youth.

[12] Arikunto, Suharsimi. 2010. Research Procedures a Practical Approach. Jakarta: Rineka Cipta.

[13] Arshad, Azhar. 2015. Learning Media. Jakarta: Raja GrafindoPersada. 
[14] Asep Jihad \& Abdul Haris. (2013). Learning Evaluation. First Printing.: Yogyakarta: Multi Presindo.

[15] Basori (2013) Utilization of Edmodo's social learning network in helping Automotive Body Theory Lecture at PTM JPTK FKIP UNS study program. JIPTEK, Vol VI, No.2, pp. 100-114.

[16] Study. (2021). Wikipedia, the Free Encyclopedia.(https://id.wikipedia.org/w/index.php ?title=Belajar\&oldid=17971360, Retrieved 19 February 2021).

[17] Bureau of Cooperation and Public Relations. (2020). Ministry of Education and Culture urgesEducators Present Fun Learning For Areas That Apply Study at home. Jakarta. Ministry of Education and Culture.

[18] Borg, WR \& Gall, MD Gall. (1983). Educational Research: An Introduction, Fifth Edition. New York: Longman.

[19] Brata, Vincent Bayu Tapa. 2010.Tips to Make Smart Phones MoreSmart Jakarta: Mediakita.

[20] Cheppy, Riyana. (2007). Video Media Development Guidelines. Jakarta: P3AIUPI.

[21] Danim, Sudarwan. (2002). Educational Innovation in Efforts to ImproveProfessionalism of Education Personnel, Bandung: Faithful Library.

[22] Dharmawan. (2013). Quantitative Research Methods. Bandung: Rosdakarya Youth.

[23] Daryanto. (2010). Learning Media has a very important role in achieving learning goals. Yogyakarta: Gava Media.

[24] Daryatmo, B. 2007. Implementation of Bluetooth Instant Messaging on DevicesMobile. STMIK GI/MDP Scientific Journal Algorithm. Vol. 3, No. 1. p. 1

[25] Dick, W., Carey, L. \& Carey, JO (2001). The systematic design of instructions (5th). NewYork: Longman.

[26] Directorate General of GTK, Ministry of Education and Culture. 2016. Technical Guidelines for Teacher Improvement ProgramLearner Mode in Network (Online). Jakarta. director General Teachers and Education Personnel.

[27] Dong, Chuanmei., Cao, Simin., Li, Hui. (2020). Young children's online learning during COVID-19 pandemic: Chinese parents' beliefs and attitudes. Children and Youth Services Review. 118(10), 1-9.
[28] Ministry of Health FAQs. (2020). Corona Virus Pandemic. Jakarta. Ministry of Health of the Republic of Indonesia Indonesia.

[29] Firdaus, Muhammad Zaki. (2018). Whatsapp Instant Messaging Application Development in Microteaching Learning as a Media ToolIndependent Learning of Automotive Engineering Education Students, Yogyakarta State University. Fac. Engineering : University of Yogyakarta.

[30] Hadisaputra, S., Gunawan, G., \&Yustiqvar, M. (2019). Effects of Green Chemistry Based Interactive Multimedia on the Students' Learning Outcomes and Scientific Literacy. Journal of Advanced Research inDynamical and Control Systems, 11(7), p. 664-674.

[31] Hadisi, L., \& Muna, W. (2015). Information Technology Management inCreating a Learning Innovation Model (E-Learning). Al-Ta'dib Journal,8(1), p. 117-140.

[32] Handarini, Oktafia Ika., Wulandari, Siti. (2020). Online Learning AsStudy From Home (SFH) Efforts During the Covid-19 Pandemic Journal Unesa, Vol. 8 (3). 496-503.

[33] Handayani, Titin Hera Widi and Chayati, Ichda. (2010). Resource UtilizationLearn the Internet to Increase Presentation Creativity in the Eyes Oriental Food Processing Lecture. Journal of Technology Education and Vocational. Vol 19(2), pp. 233-241).

[34] Herliandry, LD, Nurhasanah, N., Suban, ME, \& Kuswanto, H. (2020). Lessons Learned During the Covid-19 Pandemic JTP-JournalEducation technology, Vol. 22(1), p. 65-70.

[35] Hernawan, H. (2007). Elementary Learning Media. Bandung: Upi Press.

[36] Hutomo, Singgih. (2018). Instant Messaging service application development Whatsapp as a Source of Independent Learning to Increase Motivation and Learning Outcomes of Physics Subjects of the Greenhouse Effect of ParticipantsEducate class X sman 1 Purwokerto. Yogyakarta University.

[37] Iftitah, Selfi Lailiyatul., Anawaty, Faridhatul Mardiyana. (2020). The role of parentsIn Accompanying Children at Home During the Covid-19 Pandemic. Journal Of Childhood Education (JCE). Vol, 4(2). hlm. 71-81.

[38] Indriana, Dina. 2011. Variety of Teaching Media Aids. Yogyakarta: DIVA.Press. 
[39] Iskandar, R. (2020) Using Whatsapp Groups as Learning Media Against Didikta AT-Tawakal Participants in Bandung City. Comm-Edu Journal. Vol.3(2). p. 97-101.

[40] camp. J. E Dan Dayton, DK (1985). Planning And Production InstructionalMedia. Cambride: Harper \& Row Publishers. New York.

[41] Fart. (2009). Making media presentations. Jakarta: PustekkomKemdikbud.

[42] Kovalchick, Ann., Dawson, Kara. (2004). An Encyclopedia of EducationalTechnology. Santa Barbara: ABC-CLIO. Inc.

[43] Kuntarto, E. 2017. The Effectiveness of Online Learning Models in Lectures Indonesian Language in Higher Education. Journal of Indonesian Language Education and Literature, Vol. 3, No. 1, p. $99-110$.

[44] Matondang, Zulkifli (2009) Validity and Reliability of an Instrument Study.Tabularasa Journal, vol 6 (1). p. 87-97.

[45] Miftah, M. (2013). Functions and Roles of Learning Media as an Effort to Improve Students' Learning Ability. Kwangsan Journal, Vol. 1(2), pp: 95-104.

[46] Munadi, Yudhi. 2013. Learning Media: A New Approach. Jakarta: Reference.

[47] Pangondian, Roman Andrianto., Santosa, Paulus Insap., Nugroho, Eko. (2019). Factors Affecting the Success of Online Learning in the Industrial Revolution 4.0. UGM Yogyakarta. SAINTEX.

[48] Classroom Action Research (CAR). Jakarta: Earth Literacy. Jihad, Asep and Abdul Haris. (2012).Learning Evaluation. Yogyakarta: Multi Pressindo.

[49] Pimmer, C., Mhango, S., Mzumara, A., Mbvundula, F. (2017). Mobile instantmessaging for rural community health workers: a case from Malawi. GlobHealth Action, Vol.10(1), pp. 110-116.

[50] Poore, Megan. (2013). Using SocialMedia in the Classroom: a best practiceguides. Singapore: SAGE Publications.

[51] Indonesian Digital Portal .2020. Indonesia DigitalReport.Takenfrom(https://datareportal.com/r eports/digital-2020-indonesia, accessed 28 January 2021).

[52] Prajana, A. (2017). Utilization of the Whatsapp Application for Learning Media Within the Uin ArRaniry, Banda Aceh. Educational JournalInformation Technology. Vol. 1(2), p. 122133.
[53] Prianto.2020. Innovative Learning Methods and Techniques. Jakarta: We Write.

[54] Pujiriyanto. (2012). Technology for Media Development and Learning.Yogyakarta: UNY Press.

[55] Punaji Setyosari. (2013). Educational Research and Development Methods. Jakarta: Kencana Prenadamedia Group.

[56] Puntoadi, Danis. (2011). Creating Sales Through SocialMedia. Jakarta:PT Elex Media Komputindo.

[57] Center for Research and Development of the Ministry of National Education. (2007). Social Studies Integrated Learning Model. Jakarta: Ministry of National Education

[58] Son, Nusa. (2015). Research \& Development Research and Development: An Introduction. Jakarta: Rajawali Press.

[59] Putria, Hilna; Lutfi Hamdani Maula; Din Azwar Uswatun. (2020). Analysis Online Learning Process (DARING) During the COVID-19 Pandemic for Elementary School Teachers.Basicedu Journal, (online), Vol. 4, No. 4, p. 861-872.

[60] Radwan, E., Radwan, A. and Radwan, W., 2020. The role of social media in spreading panic among primary and secondary school students during the COVID-19 pandemic: An online questionnaire study from the Gaza Strip, Palestine. Heliyon, Vol. 6(12). pp. 01-03.

[61] Riyana, C. (2019). Production of Online Based Learning Materials. UniversityOpen.

[62] Riyanto, Orphan. 2009. New Paradigm of Learning: As a Reference forEducators in the Implementation of Effective and Quality Learning.Jakarta: Kencana.

[63] Rudi, Susilana., Cepi, Riyana, 2008. Learning Media. Bandung: CV Discourse. Prime.

[64] Rusman. (2015). Integrated Thematic Learning Theory, Practice, and Assessment. Jakarta: PT Raja GrafindoPersada.

[65] Sadiman, Arief. (2017). Educational Media; Understanding, Development, and Utilization, Jakarta: Raja GrafindoPersada.

[66] Sahidlah. (2019). WhatsApp as a student's digital literacy media. Journal of Varia Pendidikan, Vol. 31, No. 1, pp. 52-57.

[67] Sanjaya, Vienna. (2011). Educational Process Standard Oriented Learning Strategy. Jakarta: Kencana. 
[68] Sapriya. (2009). Social Studies Education. Bandung: RosdaKarya.

[69] Singh, V., \& Thurman, A. (2019). How many ways can we define online learning? Asystematic literature review of definitions of online learning. American Journal of Distance Education, 33(4), 289-306.

[70] Slamet. 2010. Learning and the factors that influence it. Jakarta: PT. Create.

[71] Slavin RE (2009). Education Psychology. Sixth Education Boston: Jakarta: Rineka Cipta

[72] Sudjana, Nana. 2009. Assessment of Teaching and Learning Outcomes. Bandung: PT. Rosdakarya Youth.

[73] Suhendi, A., \&., P. (2018). Constructivist Learning Theory: The Contribution toForeign Language Learning and Teaching. KnE Social Sciences, vol 3(4), pp. 87-95.

[74] Sukiman. (2012). Learning Media Development. Pedagogy. Yogyakarta.

[75] Supardi. (2011). Fundamentals of Social Sciences. Yogyakarta: Waves.

[76] Suprijono, Agus. 2013. Cooperative Learning Theory and Application of PAIKEM. Yogyakarta: Student Library.

[77] Supriyono, E. (2018). Soccer skills test app developmentWeb-based. Journal of Sports, Vol.6 (1), p. 38-47.

[78] Sobri, et al., 2009, Education Management, Yogyakarta: Multi Pressindo.

[79] Sofyana\& Abdul. 2019. Whatsapp-Based Combination Online Learning in the Employee Class of the Informatics Engineering Study Program, PGRI Madiun University. National Journal of Informatics Engineering Education. Volume 8 Number 1, Pg. 81-86.

[80] Sugiyono. (2013). Quantitative, Qualitative and R\&D Research Methods Bandung: Alphabeta.

[81] Susilowati. (2020). How Online Learning Amid the Covid 19 Outbreakvia WhatsApp Groups. Raflesia Journal of Mathematics Education. Vol. 05. No. 03. p. 23-24.

[82] Supardi. (2011). Fundamentals of Social Sciences. Yogyakarta: Waves.

[83] North Sumatra Province Circular No. 205 Year 2020 AboutImplementation of Learning in the 2020/2021 Academic Year and the YearAcademic 2020/2021 During the Covid-19 Pandemic of
Sumatra Province North.(2020). SUMUT. SUMUT PEMPPROV

[84] Tafonao, T. (2018) The Role of Learning Media in Increasing Interest Student Learning. Journal of Educational Communications, Vol. 2, No. 2, p. 103 113.

[85] Wati, Ega Rima. (2016). Variety of Learning Media. Yogyakarta: Pena said.

[86] Whatsapp inc. (2021). WhatsApp Messenger. Takenfrom:https://itunes.apple.com/id/app/whatsap p-messenger/id310633997? $1=$ en $\& \mathrm{mt}=8$ (https://www.kemdikbud.go.id/main/blog/2020/03/ kemendikbud-imbau- educator-present-learningpleasing-bagi-area-yang-apply-learning-di-rumah, Accessed January 27, 2021).

[87] Wina Sanjaya. 2012. Classroom Action Research. Jakarta: Kencana

[88] Wisudawati, N., Kuntarto, E., \& Kurniawan, AR (2020). Teacher's Perception Towards the Edmodo Application as a Learning Tool in Elementary Schools. Journal of Basic Education Research. Vol. 3(1), p. 87-96. 